European Research Studies, Volume XIII, Issue (1), 2010

\title{
Operational Risk Measurement
}

\author{
Gabriela ANGHELACHE ${ }^{1}$, Ana-Cornelia OLTEANU (PUIU) ${ }^{2}$, Alina-Nicoleta RADU ${ }^{3}$
}

\begin{abstract}
:
Beginning with the fact that performant strategies of the financial institutions have programmes and management procedures for the banking risks, which have as main objective to minimize the probability of risk generation and the bank's potential exposure, this paper wants to present the operational risk measurement. Therefore, the first part presents the conceptual approach of the operational risks through the point of view of the financial institutions exposed to this type of risk. The second part describes different measurement methods for the operational risk. The final part of this article presents the approach assumed by a financial institution with a precise purpose: the quantification of the minimum capital requirements of the operational risk ${ }^{*}$.
\end{abstract}

Keywords: operational risk, operational risk management, Basic Indicator Approach, Standard Approach, Advanced Measurement Approach JEL Classification: C02, G21, G32, N20

\section{Introduction}

In the last period of time the changes that took place on the financial market, because of the development of new activities and implementation of new products, generate new types of risks, more complex and bigger. A recent category is represented by the relative operational risk, for which the Basel Committee

\footnotetext{
${ }^{1}$ Prof Univ Ph.D., The Academy Of Economic Studies, Romana Square, No4, District 1, Bucharest, Tel: 004 021.319.19.00, anghelache@cnvmr.ro

$2 \mathrm{Ph} \mathrm{D}$ Assistant, The Academy Of Economic Studies, Romana Square, No4, District 1, Bucharest, Tel: 004 021.319.19.00,puiu_ana@yahoo.com

3 Ph D Assistant, The Academy Of Economic Studies, Romana Square, No4, District 1, Bucharest, Tel: 004 021.319.19.00, 004072369 57 38, alinanicoleta.radu@gmail.com

* Taking into consideration the values obtained we can mention that in the case of Standard Approach we have a different percentage of the needed capital in comparison with the Advanced Approach. Therefore in the second case we concluded that the percentage needed by a bank is 12 , which is less than 15 , the percentage needed in the first case.
} 
elaborated standards and regulations. In this way it was recognized the impact of this risk for the activity of the credit institution.

The past experiences indicated that in the case in which the financial institution has not an adequate risk management, it is exposed to jeopardis which can transform into important losses. These losses can generate even the cessation of the institution activity.

The Basel Committee considers the operational risk a distinct category, as the credit risk or the market risk. It defines the operational risks as ,the risk of direct or indirect loss resulting from inadequate or failed internal processes, people and systems or from external events". It also takes into consideration the legal risk, but excludes categorical the strategic and reputational risks.

According to Merrill Lynch, this definition does not explain clearly how should be interpreted the nature and the measure of the indirect losses. This determines the financial institutions to have their own definitions, but this will create unsubstantiality. Because of the fact the Basel Committee wanted to underline only the minimum standards for all the financial institutions, as well as the non-existence of a concrete definition of this risk, in practice were adopted the list of risk categories and the analyse of each one. The separation was made in order to cover all the possible operational risks and to concentrate the most significant causes of the loss severity met day by day.

The specialized literature presents the opinions of more authors regarding the operational risk area. Therefore in 2001, The PNC Financial Services Group recommended a more concise definition for the operational risk, a definition that should be based more on direct losses and which exclude categorical the business risk, the strategic risk and the reputational risk: ,the operational risk is the risk of the income direct loss, which results from internal events connected to inadequate personal, important errors or ilegal behaviour because of the errors or the systems and processes inadequation, or from external events where the risks are not cover by the credit, market or interest rate risk". Thus the operational risk can be interpreted as a vulnerability of the financial institution, that can be reduced or eliminated though an increased control.

\section{Approaches for the quantification of the capital need}

Basel presents three possible approaches for the quantification of the capital need: Basic Indicator Approach - the most simple way to determine the operational risk capital. It uses only one indicator as a replace for the bank general exposure at the operational risk. Basic Indicator Approach - generally, BIA is used by financial institutions which are not part of G-10, because this is the most simple way to calculate the necessary capital for the operational risk. The method uses only one index as a substitute of the general bank exposure at the operational risk. It is considered the most adequate method used until managent would dispose of proper compliance and controlling methods with a minimum work volume. So, the capital 
demand is determined by using a procent of 15 to the gross income of the bank for the last three years:

$$
K_{B I A}=\frac{\alpha \sum_{i=1}^{n} G I_{i}}{n} \quad 4 .
$$

Standard Approach - this approach supposes to organise the activity of the financial institution in 8 standard business lines. These lines use, as a common index, the gross income. So it is not a must to have operational losses calculated. This kind of approach it is used by the banks until they implement an informatic systems for the capital data, procedures to follow the internal experiences and a planning for losses. The approach supposes organising the financial institution activity in eight standard business lines which use as common index the gross income. This means that we don't need to colect data which regards the operational losses, but it has to dispose by efficient standards of the risk management. This approach is used until banks implement proper management informatic systems for the capital data which refers to the capital and different procedures that regards the internal experiences and the loss; Advanced Measurement Approach - supposes that the minimum requirements for the operational risk are determined by the internal data and models. In this case the minimum requirement of capital needed to meet operational risk is estimated on the internal methods. These methods have to be integrated by the bank risk management and also have to be validated by the supervising authority and by the specialised auditor.

Therefore, the Basel Committee offers flexibility to the financial institutions to create new methods to estimate minimum level of the own funds/ core capital needed to cover the operational risk. The minimum qualitative requirements that a financial institution have to meet are: each financial institutions has to have an independent risk division; the internal system of measuring operational risk has to be integrated by the general framework of the risk management; this means monitoring and reporting all the operations; perpetually reports have to be done for the management, the senior management, the financial institution and the activity. These models are integrated in the risk management process and validated, internal and external, by the Supervision Authority and by the specialized auditor.

To determine the capital need for the operational risk using Advanced Approach we can use one of the following methods: Internal Measurement Approach - it uses information generated by the standard approach and for each business line we have an exposure index, Loss Distribution Approach - it

\footnotetext{
${ }^{4} \mathrm{KBIA}=$ risk provisions to cover the operational risk;

$\mathrm{GI}=$ global income;

$\mathrm{n}=$ the number of last years when the global income was positive

$\alpha=15 \%$ rate
} 
determines the possible operational loss distribution for a long period of time, for each business line or risk type and Scorecard Approach - it determines an initial level for the operational risk capital. It changes in time by including the fundamental risk profile for each business line. This approach is preferred when an operational risk management is developed, because it identifies the number of risk indexes, that can indicate the fundamental risks cause. The main condition in order to develop a measurement system for the operational risk is represented by data supervision, especially the data connected to the bank current activities, technological process and the risk management procedure.

\section{Case Study}

In the following lines we want to show how the value of the capital owned by a company for the operational risk decreases when the companies start to use advanced methods. Therefore we took a Romanian financial institution. At the beginning of 2007 it used the Standard Approach for the operational risk, although its financial group used an internal model. They considered that historical data are not relevant in order to create scenarios and indexes for measuring loss.

From the eight business lines presented by the Basel Committee, the financial institution analyzed, is active just in four of them: transactions and sales, retail, commercial activity and other activities. The relevant index for all the business lines take into consideration the Gross Income because it reflects very well the operational risk sensitiveness. A dynamic approach used by the financial institution proved the increase of the events that generate risk. Also, the Standard Approach this result. From the made studies we found out that the need of capital for the operational risk is decreasing in case we use a more advanced method. The capital decrease is explained by the fact that for the Basic Indicator Approach the capital needed to cover the operational risk is $15 \%$ from the Gross Income; while in the case of the Standard Approach the risk degree is $12 \%$. This percent is the same for each business line although they are different from one another and the main business line is the retail activity.

The next stage of the article presents the level where the financial institution tried to apply LDA method to quantify the capital need for the operational risk. Therefore the activity was separated in four business lines, in same way the Basel Committee separates the activity: Retail, Commercial, Transactions and sales and Other activities. We observed that the activity developed generated losses because of the: external fraud, delivery and processes management. In this way we had twelve cells for the matrix: events/business lines. Because the data was available only at the aggregate level there were made some suppositions:

- The allocation value and the number of losses for each matrix cell were made by taking into consideration the contribution of the business line to the gross income, see Table1 and Table2. 
- The frequency follows a Poisson distribution for each the mean is equal to the variance (the $\lambda$ parameter is the mean if the month losses). For example, for the cell Retail $\lambda=4$. This means that in one month there are 4 frauds and the severity follows a Pareto process Pareto $(\theta, a)$; where the severity mean was determined as a ratio between the loss value and the number of events for each cell, Fig 1.

- The severity follows a Pareto Process $(\theta, a)$, where the severity mean was determined as a report between the loss values and the number of events for each cell. For example we take again the case of the first cell from the matrix, Fig 2.

After repeating the process described for each business line we used the Monte Carlo simulation in order to generate different scenario for the frequency and for the loss severity. The result can be seen in Fig. 3 .

We have to mention that the mean of aggregate loss distribution is equal with the product between the Poisson mean distribution and the Pareto mean distribution. For example Poisson Distribution Mean (4 loss events because of the clients, the products and the commercial practices) multiplied with Pareto Distribution Mean (loss mean is 7453, 0564 RON for the Retail activity) give us the aggregate Loss Distribution Mean (the loss in this month is 29809,5593 RON). This mean represents the provision level that has to be made by the financial institution in order to cover the medium losses that can appear normally during the activity. In conclusion, in case of loss because of the clients, products or commercial practices characteristic for the retail activity, the financial institution has to make a provision of 29809,5593 RON.

To establish the capital reserve to cover the unexpected losses there are used the repartition functions for the aggregate loss distribution for different confidence levels2 (VaR), from which the expected loss is eliminated. The expected loss has the same value for all the confidence levels.

For example, in the case mentioned before, the matrix line: business and the event: retail activity, the results were:

- if the financial institution wants to cover the medium losses generated by the clients, products or commercial practices, it has make a provision of 29812,22561 RON;

- if the financial institution wants to protect the stability of this business line against the losses generated by the clients, products or commercial practices, it has to create a supplementary capital to cover different potential loss of 52494,3142 RON (for this case Basel Committee recommendation is respected, the confidence gap in $99.9 \%$ );

- in the case this institution doesn't create the reserves presented, in a month the institution can have losses generated by the clients, products or commercial practices of $82306,5398 \mathrm{RON}$. This losses can affect both the profitability and the shareholders financial results. For a trust interval of $99.9 \%$ there is $0.1 \%$ 
chances to have a loss of $82306,5398 \mathrm{RON}$. This is the reason that a lot of authors considers the Basel standard very strict and prefers a trust interval between $95 \%$ and $99 \%$.

\section{Conclusions}

Taking into consideration the values obtained we can mention that in the case of Standard Approach we have a different percentage of the needed capital for each business line and the main activity developed by the financial institution is the retail activity. Also for the Loss Distribution method, we can consider that the simulation results are transparent and very easy to interpret and the repartition function for different trust interval is very easy to view. That is why we can consider it a very good instrument in generating the aggregate loss and the information need by the risk managers.

In time, by applying the Basic Indicator Approach or the Standard Approach we realized that between the capital level and the level of the operational risk we can not establish a clear connection, because there are a lot of situations when the financial institutions are exposed to important risks and they do not calculate a correct limit to protect themselves.

\section{References:}

1. Anghelache, G., 2007, “Acordul Basel II, provocări pentru autorităţile de supraveghere, instituţiile de credit şi firmele de investiţii” Managementul riscului in perspective Basel II ediția a IV- a Bucureşti.

2. Barbu, T, Bunea D., 2007, "Riscul operațional: Modalități de Cuantificare şi Gestionare" manuscris

3. Basel Committee on Bank Supervision, 2006, "International Convergence of Capital Measurement and Capital Standards" pg 144-156, 207, 217, 302-307 www.bis.org

4. Basel Committee on Bank Supervision, 2001, "Operational Risk", www.bis.org

5. Baud N., Frachot A., Roncalliy T., 2006, “An Internal Model for Operational Risk Computation" http://www.risklab-madrid.uam.es/

6. Bejenaru A., 2006, "Cerințe privind perfecționarea managementului riscului în instituțiile de credit - Acordul Basel II" Revista Finanțe Publice şi Contabilitate Nr. 6 pg. 17-22

7. Bessis J., 1999 , "Risk Management in banking” ed Willy pg 20-21 48-49

8. Boulescu M., 2005, "Riscul operațional şi riscurile asociate activităților externalizate" Tribuna Economica Nr 42 pg 32-36, 39

9. Chernobai A., Svetlozar T. R., 2006, "Applying Robust Methods to Operational Risk Modeling"

10. Courage G., 2001, "Loss Distribution Approach" Capital Allocation for Operational Risk Conference Boston 
11. Deaconescu D., 2005, "Rolul sistemului bancar în realizarea dezvoltării durabile a economiei româneşti” - Coordonator: Prof. univ. dr. Constantin Manolescu pg 211-236

12. Dutta K., Perry J., 2007, “A Tale of Tails: An Empirical Analysis of Loss Distribution Models for Estimating Operational Risk Capital" http://www.bos.frb.org/economic/wp/index.htm

13. Frachot A., Roncalli T. and Salomon E., 2004, "The Correlation Problem in Operational Risk" Groupe de Recherché Opérationnelle Group Risk Management, Crédit Agricole SA, France

14. Frachot A., Georges P. \& Roncalli T., 2001, "Loss Distribution Approach for operational risk" Groupe de Recherché Opérationnelle, Credit Lyonnais, France

15. Georgescu F., 2007, "Bilanțul evoluției sistemului bancar la un an de la aderarea la Uniunea Europeana" www.bnro.ro

16. Georgescu F., 2005, "Stadiul pregătirii pentru aplicarea reglementarilor Basel II în sistemul bancar romanesc" www.bnro.ro

17. Henie von G., Sanja B. B., 2004, "Analyzing and Managing Banking Risk”, editura Irecson, pg 66-84, 128-137

18. Junji H., 2002, "Solutions on Measuring Operational Risk", Capital markets news

19. Isaic-Maniu I., 2006 "Caracterizarea statistica a riscului", editura ASE București, pg 115-125

20. Iuga I., Socol A., 2006, "Procesul de management al riscului operațional în cadrul băncilor româneşti” revista Finanțe Bănci Asigurări Nr. 10 pg 51-53

21. Jordan J., 2004, "Operational Risk A Discussion of Quantification Techniques" Federal Reserve Bank of Boston

22. Keller James S., 2001, "Request for Comments on The New Basel Capital Accord" The PNC Financial Services Group, Inc. ("PNC"), Pittsburgh, Pennsylvania

23. Merrill Lynch \& Co., Inc, 2001, "Merrill Lynch response to the Basel Committee and European Commission" New York

24. Navarrete E., 2006, "Practical calculation of expected and unexpected losses in operational risk by simulation methods" Banca \& Finanzas, Documento de trabajo No.1

25. Shevchenko Pavel V., 2004, "Valuation and Modeling Operational Risk: Advanced Measurement Approach" CSIRO Mathematical and Information Sciences, Sydney, Australia

26. Tinca A., 2006, "The Operational Risk in the Outlook of the Basel II Accord Implementation" pg 31-34 www.ectap.ro/articole/217.pdf

27. Zentralerkreditausschuss, 2001, "Comments of the Zentraler Kreditausschuss on the Basel Committee's Consultative Document of 16 January 2001 on a New Capital Adequacy Framework for Banks ("Basel II")" Berlin 


\section{TABLES}

Table 1 the loss value on event and business line, as a percentage from the aggregate loss

$\begin{array}{llll}\text { Business Line / Event/ } & \begin{array}{l}\text { External } \\ \text { Severity }\end{array} & \begin{array}{l}\text { Clients, products and } \\ \text { commercial practices }\end{array} & \begin{array}{l}\text { Execution and } \\ \text { delivery of the } \\ \text { processes }\end{array} \\ \text { Retail } & 1,1776 \% & 13,7384 \% & 24,3365 \% \\ \text { Commercial } & 1,0532 \% & 12,2879 \% & 21,7671 \% \\ \text { Transactions and Sales } & 0,1799 \% & 2,0988 \% & 3,7178 \% \\ \text { Other Activities } & 0,5893 \% & 6,8750 \% & 12,1785 \%\end{array}$

Source: proper processing

Table 2 the number of losses on events and business lines, as a percentage from the total loss

$\begin{array}{lllll}\text { Business Line } \quad \text { Event/ } & \begin{array}{l}\text { External } \\ \text { Fraud }\end{array} & \begin{array}{l}\text { Clients, products and } \\ \text { commercial practices }\end{array} & \begin{array}{l}\text { Execution and } \\ \text { delivery of the } \\ \text { processes }\end{array} \\ \text { Retail } & 20,8036 \% & 4,2857 \% & 14,0179 \% \\ \text { Commercial } & 18,6607 \% & 3,8393 \% & 12,6786 \% \\ \text { Trading and Sales } & 3,2143 \% & 0,7143 \% & 2,1429 \% \\ \text { Other activities } & 10,4464 \% & 2,1429 \% & 7,0536 \%\end{array}$

Source: proper processing

\section{GRAPHICS}

Fig 1: Frauds distribution in one month for the retail activity

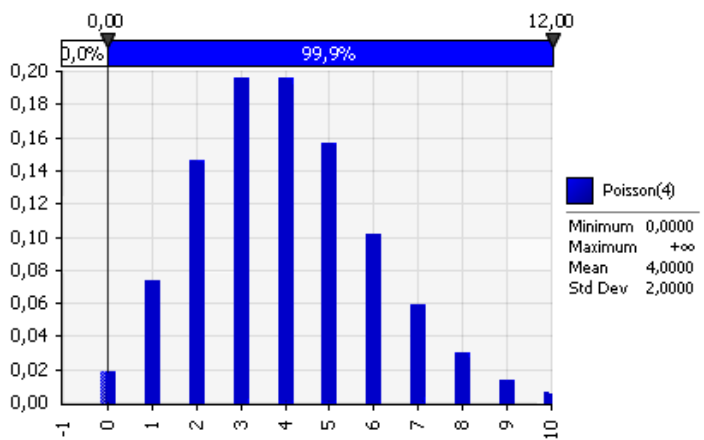

Fig 2: Loss value distribution for the retail activity because of the clients, products and commercial practices 


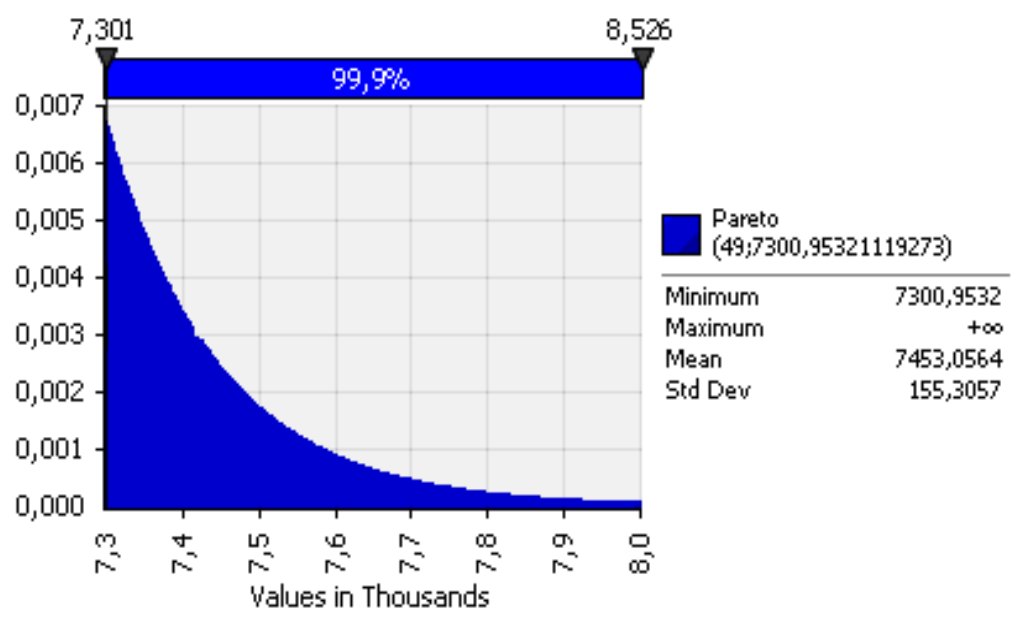

Fig. 3: The aggregate loss distribution

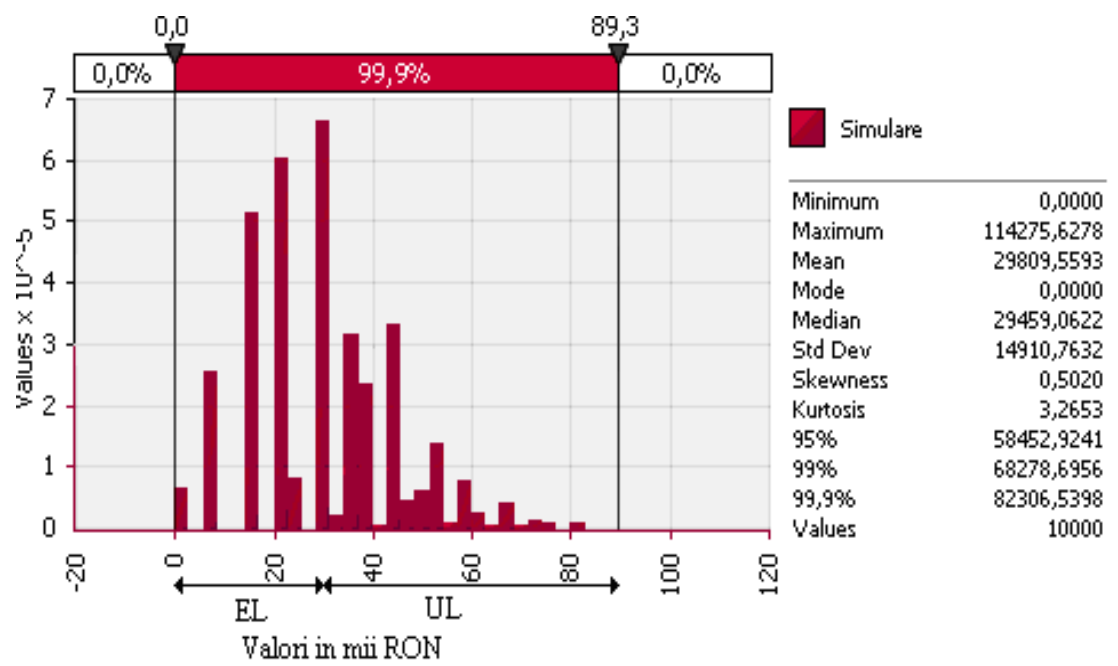

